\title{
Impact of High Pressure Rotorvane on CTC Black Tea Quality
}

\author{
Cosmas K. Langat， Abel N. Mayaka， Charles M. M. Ondieki
}

\begin{abstract}
Conventional black tea is produced using variety of tea leaves called Camellia sinensis (species of evergreen shrub or small tree whose leaves and leaf buds are used to produce black tea). Black tea processing production involve plucking, withering, maceration/rolling, cutting, oxidation/fermentation and drying. In the conventional black tea process, CTC (Cutting, Tearing and Curling) is where tea leaves are cut to rapture plant cells so as to release catechins for oxidation / fermentation for 2 hours before being stopped in the dryer at a temperature of $1300 \mathrm{C}$. The CTC tea manufacturing process produces high quality teas. High pressure Rotorvane has been designed for processing of Orthodox teas [1] by converting standard Rotorvane from Low to high Pressure [2] and tested to produce Orthodox Large Particle Tea that is able to infuse like normal conventional black CTC teas [3]. To check impact of high pressure Rotorvane on CTC black tea, factory trials were done using 15" Rotorvane at different pressures and were then tracked through the innovation manufacturing process. Made tea samples for each trial were drawn and assessed by tea tasters for quality using the Unilever International Tea Categorisation System (ITCS) and quality comparisons made. It was found out that the higher the Rotorvane pressure the higher the quality of CTC made tea to an optimum level of $25 \mathrm{MN} / \mathrm{m} 2$ on quality parameters of Taste, Colour and Mouthfeel giving a taste score of 5.4 which is 0.4 above conventional CTC made tea quality of 5.0. Leaf appearance score remained the same at 5. From the conclusion obtained, high pressure Rotorvane should be used as a standard equipment in the processing of high-quality CTC teas in the Tea industry.
\end{abstract}

Index Terms - Camellia sinensis, Rotorvane, Orthodox Tea, CTC, Black Tea, Pekoe Fannings.

\section{INTRODUCTION}

The conventional CTC black tea process involves withering finely plucked leaf from $78 \%$ moisture content to $70 \pm 2 \%$ moisture content [4]. The withered leaf is passed through a standard Rotorvane at a pressure of about $5 \mathrm{MN} / \mathrm{m}^{2}$ [4]. The macerated leaf (ex-Rotorvane) is passed through a triplex CTC, fermented for 2 hours before drying and sorting into various grades [4]

Eng. Cosmas K. Langat, +254 780 490433, MSc student - Mechanical Engineering, Faculty of Engineering and Technology, Multimedia University of Kenya

Prof. (Eng.) Abel N. Mayaka, +254 723 082890, Professor of Manufacturing Engineering, (PhD - Technical Sciences), MSc. in Mechanical Engineering, Senior Lecturer - Faculty of Engineering and Technology, Department of Mechanical and Mechatronics Engineering (Multimedia University of Kenya)

Prof. Charles M. Ondieki, +254 722 705609, Professor of Manufacturing Engineering, PhD - Engineering Management, MSc. in Mechanical Engineering, Fellow Member (Institution of Engineering Technologists and Technicians - IET), Chairperson (Technical and Vocational Education and Training Authority - TVETA)
The black tea process flow chart is as shown below:

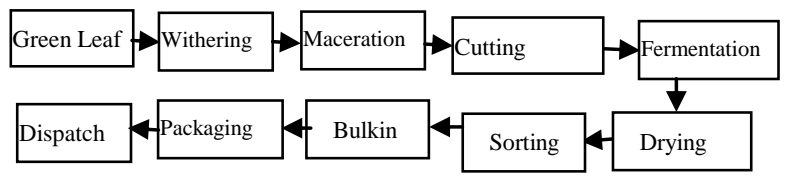

Fig. 1: Black Tea Manufacturing Process [1] [4]

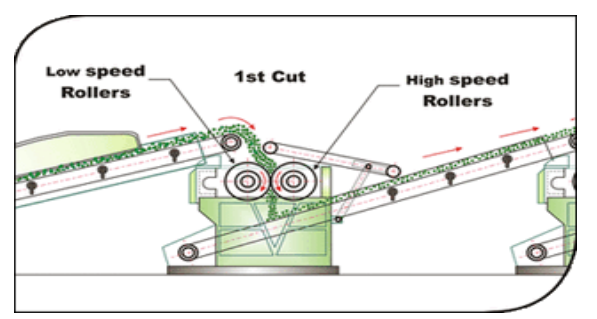

Fig. 2: CTC process [4], [1]

CTC (cutting, tearing and curling), at the cutting stage, in conventional black tea process opens up catechins in plant cells in leaves that later oxidises in the fermentation stage thus producing high quality teas with good attribute of taste (flavour), hue/colour and mouthfeel when infused [5].

The aim of this research paper is to check impact of high pressure Rotorvane [1] designed for Orthodox tea processing on the quality of CTC teas by subjecting the withered leaf to a high pressure above conventional manufacturing pressure of 5 $\mathrm{MN} / \mathrm{m}^{2}$ to rapture leave plant cells so as to release the catechins for the fermentation process before passing the leave through CTC for more release of catechins. The added Rotorvane pressure will enable the modified CTC process to release more catechins for oxidation than the conventional process thus possibly achieve higher made tea quality.

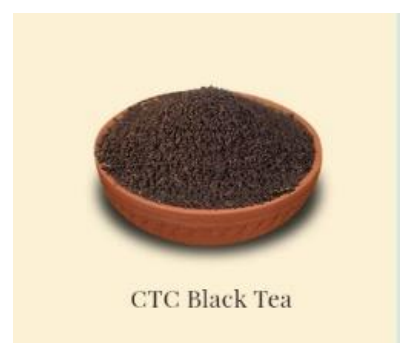

Plate 1: CTC made tea images [1]

\section{MATERIALS AND METHODS}

\section{A. Equipment and Experiments Set up}

This research experiments were conducted using 15" high Pressure full-scale factory Rotorvane as designed [1], fabricated and after dry run of all the components [2]. 
Rotorvane barrel wall (on the inside) was fitted with a pressure sensor. As the Rotorvane vanes press leaf against the resistors (bolted onto the Rotorvane barrel), the sensors pick up the pressure (stress) signal which is converted to a digital electronic form and displayed in the data logger screen every minute. The electronic data logger displays readings in Pascal (Pa, N/m²). (fig. 4).

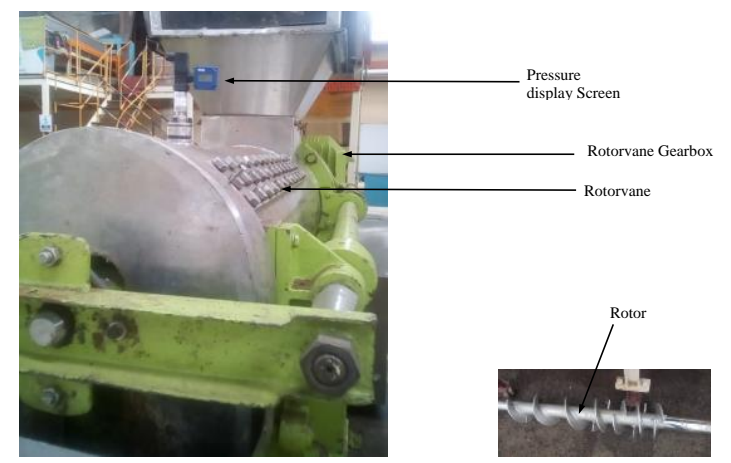

Plate 2: Rotorvane fitted with pressure gauge [1], [4]

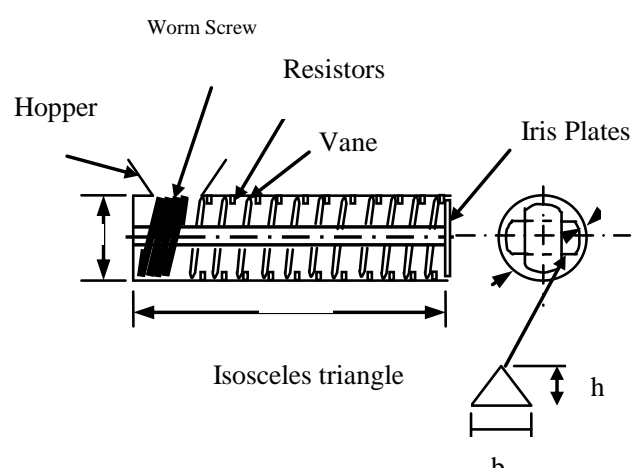

Fig. 2a: Rotorvane Sketches [1], [2]

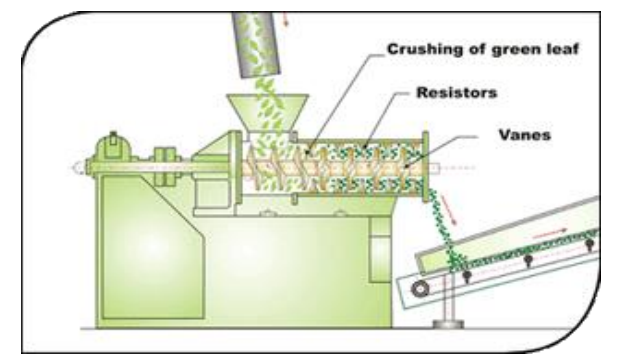

Fig. 2b: Rotorvane Sketches [1], [4]

Leaf at normal manufacturing plucking standards of $65 \%$ acceptable were withered to $70 \pm 2 \%$ Moisture Content [6] and passed through the high pressure Rotorvane set to $5 \mathrm{~cm}$ iris opening at the following different throughputs (different pressures):

i) $1000 \mathrm{~kg} / \mathrm{hr}$ (at $5.2 \mathrm{MN} / \mathrm{m}^{2}$ (Conventional CTC tea setting)

ii) $1100 \mathrm{~kg} / \mathrm{hr}\left(\right.$ at $10.9 \mathrm{MN} / \mathrm{m}^{2}$ )

iii) $1300 \mathrm{~kg} / \mathrm{hr}\left(\right.$ at $16.5 \mathrm{MN} / \mathrm{m}^{2}$ )

iv) $1500 \mathrm{~kg} / \mathrm{hr}\left(\right.$ at $\left.20.1 \mathrm{MN} / \mathrm{m}^{2}\right)$

v) $1750 \mathrm{~kg} / \mathrm{hr}\left(\right.$ at $\left.24.9 \mathrm{MN} / \mathrm{m}^{2}\right)$

Rotorvane pressures for each trial were measured and monitored. The data logger was set to record an average figure every 4 minutes. The trials ran for 1 hour at the Rotorvane.
Similar leaf is also passed through a standard Rotorvane and triplex CTC at $1000 \mathrm{~kg} / \mathrm{hr}$ of withered leaf for comparison, as a control experiment for standard quality comparison.

The leaf was tracked through the manufacturing process. 5 repeats for each set were done. Samples for Pekoe Fannings PF1 grade were collected. All samples were sent to a panel of tea tasters for made tea quality assessment using the Unilever International Tea Categorisation System (ITCS).

The research was conducted at Unilever Tea Kenya Limited Kericho in conjunction with Multimedia University of Kenya, Department of Mechanical and Mechatronics Engineering. All the materials were sourced from Unilever.

\section{B. Tea Tasting Scoring Method [6]}

The standard Tea Taster's methodology for the Unilever International Tea Categorisation System (ITCS) is 5.6 grams of tea in $280 \mathrm{ml}$ of water. The taste batch preparation methodology for its prime grade, PF1, as per the following stages:

- 5.6 grams of tea placed in a tasting mug

- $280 \mathrm{ml}$ of freshly boiled de-ionised water is added to the tea

- Brew is timed for 6 minutes

- The liquor is tipped into the tasting bowl

- The tea is tasted black with no additions for LYL blend With grades to be assessed for the European Market, the preparation methodology is the same except that milk (preferably $5 \mathrm{cc}$ of semi skimmed milk) is added to the bowl before the liquor is tipped. The liquor assessment is made using the International Tea Categorisation System and a brief description is given as a guide. There are four attributes that have to be scored. Taste and Mouthfeel that relate to taste and Colour that is a visual attribute.

The tea characteristics are scored on a scale, 0.6 score being the lowest and 9.4 score being the highest and moves up / down in steps of 0.2 score. 5.0 score is the mid-point and is where Lipton Yellow Label (LYL423) blend is rated for each attribute. A brief description is given in table I below to help interpretation:

Table I: ITCS tea tasting and scoring scale [6]

Without milk

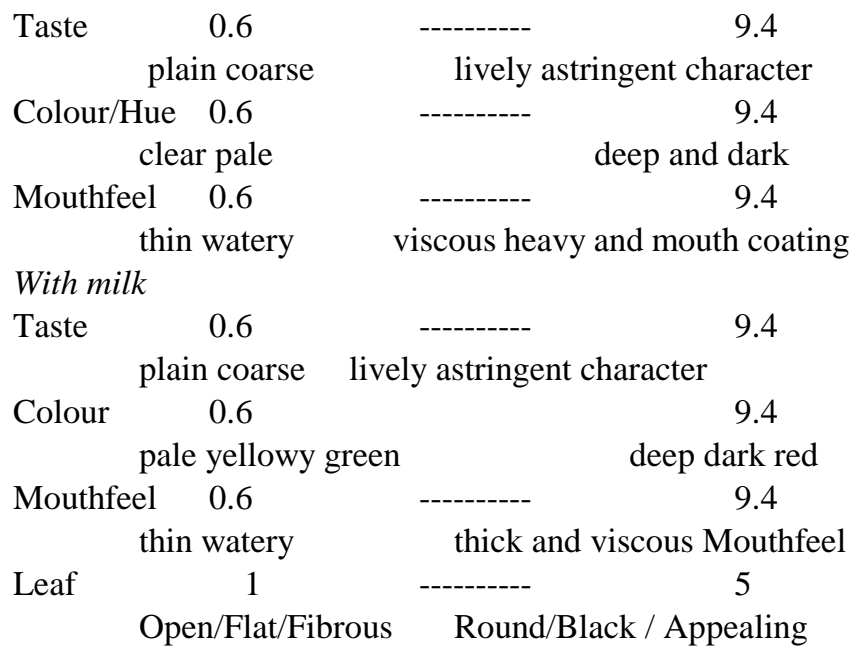

Reference teas of known characteristics need to be liquored at the front of any batch as a benchmark, only then can accurate assessments be made for Taste, Colour, Mouthfeel and Leaf 
appearance. There are a range of reference standard blends that can be used and their ITCS characteristics are as follows:

Table II. ITCS tea tasting standard reference samples [6]

$\begin{array}{lllll} & \text { T } & \text { C } & \text { M } & \text { L } \\ \text { LYL 423 } & 5.0 & 5.0 & 5.0 & 5 \\ \text { LYL 505 } & 5.0 & 4.4 & 4.4 & 5 \\ \text { LYL 640 } & 5.0 & 4.0 & 4.0 & 5 \\ \text { PG TB } & 4.8 & 5.0 & 4.8 & 5\end{array}$

PF1 grade recently scored by the tea buyers or Unilever Tea Kenya, Sales and Marketing department can be used as reference tea.

\section{RESULTS AND DISCUSSIONS}

\section{A. Tea Tasting Results and Discussion (Factory Trials)}

The tea tasters tasted made tea samples from each set of performance and optimization trials. Tasting results (appendix 5) for PF1 grade on Taste (T), Hue / Colour(C), and Mouthfeel (M) and Leaf (L) are summarised graphically as shown below:

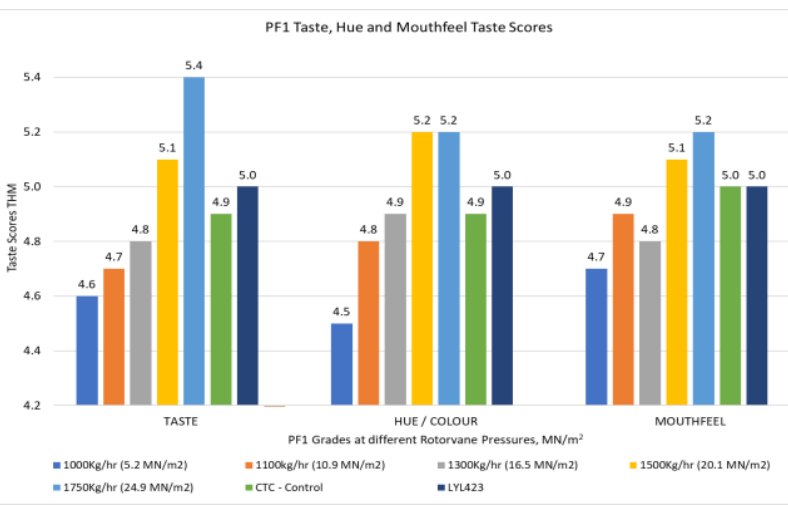

Fig. 3: PF1 Taste, Hue and Mouthfeel Scores

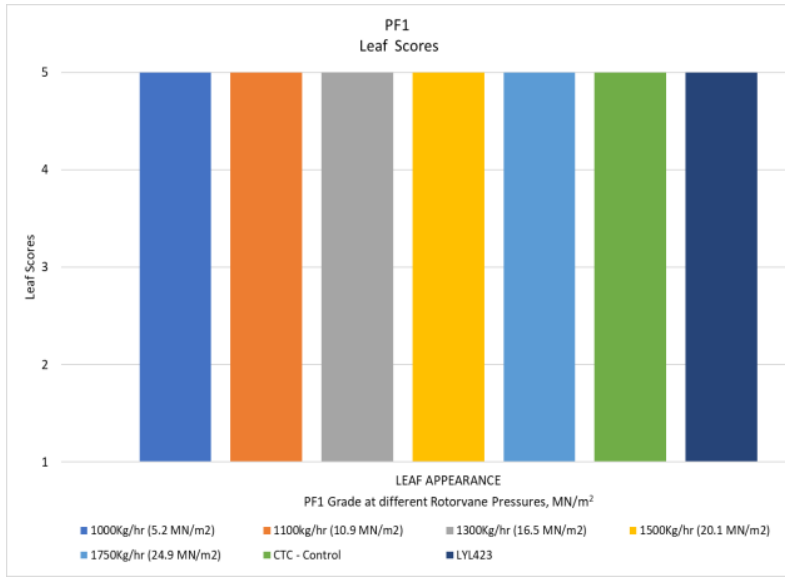

Fig. 4: PF1 Leaf Scores

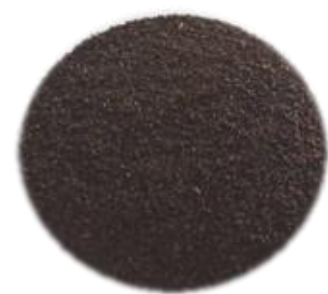

Plate 3: CTC black tea from trials at $25 \mathrm{MN} / \mathrm{m}^{2}$

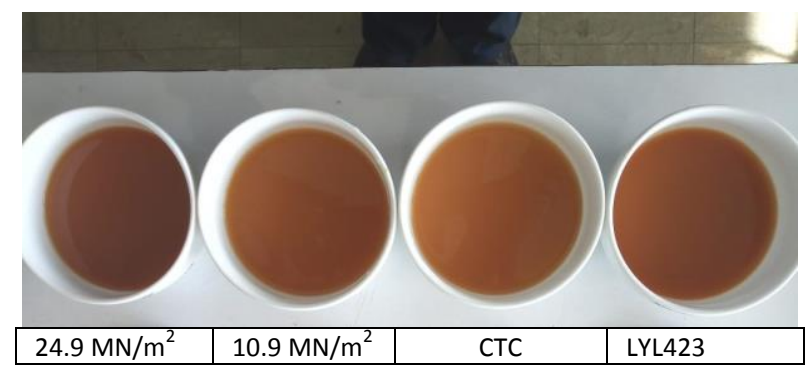

Plate 4: CTC and Orthodox Tea Quality (with milk)

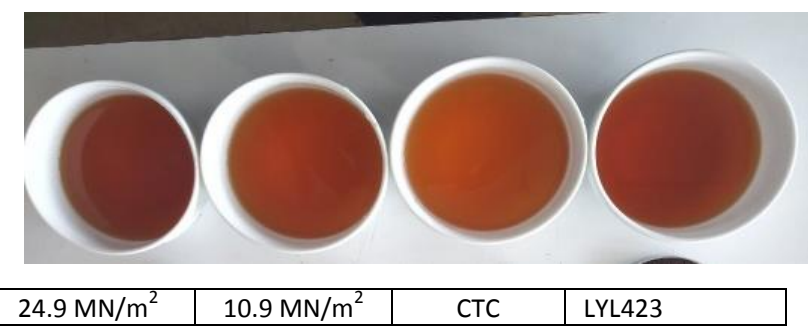

Plate 5: CTC and Orthodox Tea Quality (without milk)

From the high pressure Rotorvane factory trials on CTC teas the following were observed:

i) There was no impact in the rest of the manufacturing processes (withering, drying, sorting, etc.) on the various Rotorvane throughputs.

ii) Pressure was increased at an average of $4.9 \mathrm{MN} / \mathrm{m}^{2}$ for each set of trials.

iii) For the sampled PF1 grade:

- Taste improved from 4.6 score at $5.2 \mathrm{MN} / \mathrm{m}^{2}$ to 5.4 score at $24.9 \mathrm{MN} / \mathrm{m}^{2}$. There was an improvement of an average 0.2 score in every step. This is against LYL423 standard of 5.0 score.

- Colour improved from 4.5 score at $5.2 \mathrm{MN} / \mathrm{m}^{2}$ to 5.2 score at $24.9 \mathrm{MN} / \mathrm{m}^{2}$. There was an improvement of an average of 0.2 score in every step. This is against LYL423 standard of 5.0 score.

- Mouthfeel improves from 4.7 score at $5.2 \mathrm{MN} / \mathrm{m}^{2}$ to 5.2 score at $24.9 \mathrm{MN} / \mathrm{m}^{2}$. There was an improvement of an average of 0.1 score in every step. This is against LYL423 standard of 5.0 score.

- Leaf appearance score remain unchanged at a score of 5 for all pressure points $\left(5.2 \mathrm{MN} / \mathrm{m}^{2}\right.$ to $\left.24.9 \mathrm{MN} / \mathrm{m}^{2}\right)$. This is against LYL423 standard score of 5.0.

iv) PF1 International Tea Categorisation System (ITCS) scores at $24.9 \mathrm{MN} / \mathrm{m}^{2}$ Rotorvane pressure is better than standard CTC made tea quality on taste, colour (hue) and mouthfeel with no change in leaf appearance. The optimum pressure for high pressure Rotorvane is 24.9 (approx. 25) $\mathrm{MN} / \mathrm{m}^{2}$. Beyond $25 \mathrm{MN} / \mathrm{m}^{2}$ the Rotorvane chokes often and leaf flow become erratic (inconsistent).

\section{CONCLUSIONS AND RECOMMENDATIONS}

\section{A. Conclusions}

i) For CTC PF1 grade, the higher the Rotorvane pressure the higher the made tea quality up to an optimum of $25 \mathrm{MN} / \mathrm{m}^{2}$, which gives the highest quality on Taste (T), Colour (C) and Mouthfeel (M) scores and higher than conventional CTC made tea quality by 0.5 on Taste, 0.3 on Colour and 0.2 on Mouthfeel, and with no impact in the rest of the manufacturing processes (withering, drying, sorting, etc.). 


\section{B. Recommendation}

i) From the studies, high pressure Rotorvane should be used as a standard equipment in the processing of high-quality CTC teas in the Tea industry.

\section{Recommendation for Further Work}

i) Since there is a direct correlation between pressure and made tea quality, there is need to develop and/or do further redesign and fabrications at the Rotorvane so that it can handle pressures higher than $25 \mathrm{MN} / \mathrm{m}^{2}$ with a smooth consistent flow. Since the Rotorvane may be limited on this, it may involve investigation on the usage of other tea maceration machines other than the Rotorvane.

\section{ACKNOWLEDGMENT}

Special thanks go to Unilever Tea Kenya Limited for allowing this research to take place in their factory in Kericho.

\section{REFERENCES}

[1] C. K. Langat, A. N. Mayaka and C. M. Ondieki, "Design of High Pressure Rotorvane for Quality in Orthodox Tea Processing," Journal of Multidisciplinary Engineering Science and Technology, vol. 6, no. 9, 2019.

[2] C. K. Langat, A. N. Mayaka and C. M. Ondieki, "Fabrication of High Pressure Rotorvane for Quality in Orthodox Tea Processing "to be published"," International Journal of Latest Trends in Engineering and Technology, vol. 14, no. 4, 2019.

[3] C. K. Langat, A. N. Mayaka and C. M. Ondieki, "Optimization of High Pressure Rotorvane for Quality in Orthodox Tea Processing," Journal of Multidisciplinary Engineering Science and Technology, vol. 6, no. 9, 2019.

[4] Janice Coyle, "CTC, Orthodox Rollers and Rotorvane Layouts and Diagrams," $2006 . \quad$ [Online]. Available: http://janicecoyle.weebly.com/udhagamandalam-india.html. [Accessed 17 Jun 2018].

[5] P. O. Owuor, C. O. Othieno and T. Tadakazu, "Effects of Maceration Method on the Chemical Composition and Quality of Clonal Black Teas," ResearchGate, 1989.

[6] M. Koech, Kericho Factory Standard Operating Procedure. Kericho, Kenya., Kericho, Kenya: Unilever Tea kenya Limited, 2008.

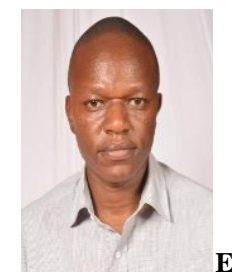

Eng. Cosmas K. Langat, +254 780 490433, MSc student - Mechanical Engineering, Faculty of Engineering and Technology, Multimedia University of Kenya, B. Tech (Production Engineering), Professional Engineer (Engineers Board of Kenya), Corporate Member (Institution of Engineers of Kenya), 1 peer reviewed journal paper.

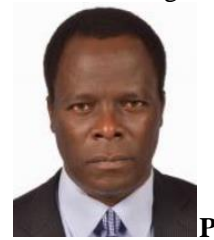

Prof. (Eng.) Abel N. Mayaka, +254 723082890 Professor of Manufacturing Engineering, (PhD - Technical Sciences), MSc. in Mechanical Engineering, Senior Lecturer - Faculty of Engineering and Technology, Department of Mechanical and Mechatronics Engineering (Multimedia University of Kenya), Professional Engineer (Engineers Board of Kenya - EBK), Corporate Member (Institution of Engineers of Kenya). He has over forty five publications in referred conference proceedings and journals. He is a member of Manufacturing and Technology Research Chair hosted by Jomo Kenyatta University of Agriculture and Technology (JKUAT) in Kenya

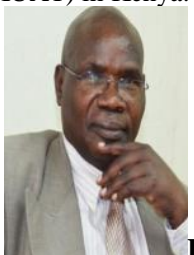
of Manufacturing Engineering, PhD - Engineering Management, MSc. in Mechanical Engineering, Fellow Member (Institution of Engineering Technologists and Technicians - IET), Chairperson (Technical and Vocational Education and Training Authority - TVETA), Senior Lecturer Faculty of Engineering and Technology, Department of Mechanical and Mechatronics Engineering (Multimedia University of Kenya) 